\title{
PENGETAHUAN MASYARAKAT TERHADAP GAYA HIDUP DI RUMAH SAJA PADA ERA NEW NORMAL
}

\author{
Mariatul Fadilah', ${ }^{1}$ Pariyana $^{2}$, Levanya Anbalagan ${ }^{3}$, Rahma Nur Islami ${ }^{3}$, Rizma Adlia \\ Syakurah $^{4}$ \\ Konsil Kedokteran Indonesia, Indonesia ${ }^{1}$ \\ Bagian IKM-IKK, Fakultas Kedokteran, Universitas Sriwijaya² \\ Program Studi Pendidikan Dokter, Fakultas Kedokteran, Universitas Sriwijaya ${ }^{3}$ \\ Program Studi Ilmu Kesehatan Masyarakat, Fakultas Kesehatan Masyarakat, Universitas Sriwijaya ${ }^{4}$ \\ rizma.syakurah@gmail.com
}

\begin{abstract}
Covid-19 has forced people to stay at home to prevent the spread of the virus from outside. Staying at home alone makes most people less physical activity and consume a lot of food. This study aims to analyze people's knowledge of the lifestyle at home in the new normal era. This research is a descriptive analysis using a quasi-experimental design pre and posttest via online seminars is used. Analytical analysis using wilcoxon test. The distribution based on age was mostly found in those under 21-44 (76.3\%), the most involved respondents were women (68.8\%). Most of the people have not worked (43.0\%). The highest level of education in this study was Bachelor's degree (69.9\%). Before the online seminar was held, it was found that $88.2 \%$ of the people could answer the pretest questions well and increased after the post-test, which was $94.6 \%$. Normality test shows an abnormal and significant distribution in the wilcoxon test. There is a difference in knowledge before and after the online seminar regarding the influence of society on lifestyle at home during the new normal era.
\end{abstract}

Keywords $\quad$ : Covid-19, Lifestyle, Behavior

\begin{abstract}
ABSTRAK
Covid-19 membuat masyarakat untuk tetap berada di rumah demi mecegah penularan virus yang ada di luar. Diam di rumah saja membuat sebagian besar masyarakat kurang beraktifitas fisik dan banyak mengonsumsi makanan. Penelitian ini bertujuan untuk menganalisis pengetahuan masyarakat terhadap gaya hidup di rumah saja pada era new normal. Penelitian ini merupakan analisis deskriptif dengan menggunakan desain quasi eksperimental pre dan post-test melalui seminar online. Analisis analitik menggunakan uji wilcoxon. Distribusi berdasarkan usia terbanyak ditemukan pada usia di bawah 21-44 (76,3\%), responden yang banyak terlibat yaitu perempuan $(68,8 \%)$. Sebagian besar masyarakat belum bekerja $(43,0 \%)$. Tingkat pendidikan yang tertinggi dalam penelitian ini adalah Sarjana $(69,9 \%)$. Sebelum diadakan seminar online, diperoleh sebesar $88,2 \%$ masyarakat yang dapat menjawab pertanyaan pretest dengan baik dan meningkat setelah dilakukan post-test yaitu menjadi sebesar 94,6\%. Uji normalitas menunjukan distribusi yang tidak normal dan signifikan dalam uji wilcoxon. Terdapat perbedaan pengetahuan sebelum dan sesudah dilakukan seminar online tentang pengaruh masyarakat terhadap gaya hidup di rumah saja pada era new normal.
\end{abstract}

Kata Kunci : Covid-19, Gaya Hidup, Perilaku

\section{PENDAHULUAN}

Coronavirus (Covid-19) adalah penyakit menular yang disebabkan oleh coronavirus yang baru ditemukan pada tahun 2019 di Wuhan, China. Sebagian besar orang yang terinfeksi virus Covid-19 akan mengalami penyakit pernapasan ringan hingga sedang dan sembuh tanpa memerlukan perawatan khusus. Orang yang lebih tua, dan memiliki penyakit komorbid seperti kardiovaskular, diabetes, penyakit pernapasan kronis, dan kanker lebih mungkin mengembangkan penyakit serius (WHO, 2021).

Secara global, lebih dari 17 juta kasus Covid-19 yang telah dikonfirmasi dan dilaporkan. Hitungan kasus yang diperbarui 
ditemukan di situs website Organisasi Kesehatan Dunia dan Pusat Pencegahan dan Pengendalian Penyakit Eropa. Peta interaktif yang menyoroti kasus yang dikonfirmasi di seluruh dunia dapat ditemukan di sini. Sejak laporan pertama kasus dari Wuhan, sebuah kota di Provinsi Hubei Cina, pada akhir 2019, kasus telah dilaporkan di semua benua, kecuali Antartika (Kanneth, 2020).

Pandemi Covid-19 terus berkembang di hampir semua wilayah dan daerah, berbagai tindakan perlindungan telah diperkenalkan oleh pihak berwenang, termasuk penutupan sekolah dan universitas, dan larangan perjalanan, acara budaya dan olahraga, dan pertemuan sosial (Hammami et al., 2020). Orang-orang telah diperintahkan atau disarankan untuk tinggal di rumah. Semua tindakan ini dilakukan sebagai strategi yang efektif untuk mencegah virus menyebarkan dan mengelola mereka yang terjangkit virus. Banyak orang mengikuti untuk mengisolasi diri dan tetap di rumah, tetapi tindakan ini akan berdampak negatif terhadap perilaku aktivitas fisik orang lain, dengan lebih banyak waktu dipergunakan untuk duduk menonton layar dan dampak selanjutnya pada kesehatan fisik (Pedersen et al., 2015).

Gaya hidup dapat berubah secara substansial karena langkah-langkah penahanan, dengan risiko akibatnya perilaku menetap, modifikasi dalam merokok dan kebiasaan tidur (Renzo et al., 2020). Menurut studi diferensial Muscogiuri, et al. (2020) dilaporkan hubungan antara gangguan tidur dan obesitas untuk meningkatkan sekresi sitokin pro-inflamasi oleh peningkatan adiposa viseral yang dapat berkontribusi untuk mengubah ritme tidur-bangun (Muscogiuri et al., 2020). Pola makan juga sebenarnya sangat memengaruhi kualitas tidur, baru-baru ini dalam sebuah studi cross-sectional yang melibatkan 172 orang dewasa yang sedang tidur, dilaporkan bahwa orang yang tidur nyenyak memiliki kepatuhan yang lebih tinggi terhadap diet Mediterania (MD) dan indeks massa tubuh lebih rendah (BMI) dibandingkan dengan orang yang kurang tidur (Muscogiuri et al., 2019).

Tingkat aktivitas fisik yang rendah menyebabkan lemak tubuh dan disregulasi nafsu makan. Kebiasaan makan dan modifikasi gaya hidup dapat mengancam kesehatan manusia. Mempertahankan status gizi yang benar adalah sangat penting, terutama pada masa sistem kekebalan tubuh mungkin perlu kembali. Didapati orang yang $\left(B M I \geq 40 \mathrm{~kg} / \mathrm{m}^{2}\right)$ adalah salah satu kelompok dengan risiko lebih tinggi untuk komplikasi Covid-19 (CDC, 2021a).

Oleh karena itu, meningkatkan hidup sehat dengan mempromosikan langkahlangkah pencegahan yang efektif untuk mencegah munculnya kerentanan terhadap pandemi seperti karena Covid-19. Beberapa uji klinis, seperti Pencegahan Primer Penyakit Kardiovaskular dengan Diet Mediterania (PREDIMED), studi diet India dan Mediterania, dan percobaan Canakinumab Anti-Inflammatory Thrombosis Outcome Study (CANTOS) telah memberikan harapan hasil, yang menyarankan pengurangan yang mungkin dan pengobatan penyakit radang kronis yang berhubungan dengan gaya hidup (Boroujeni et al., 2020).

Tidak hanya Covid-19, tetapi juga beragam penyakit mulai dari kanker hingga gangguan autoimun serta respons imun yang tidak terkontrol merupakan kontributor utama kerusakan respon imun yang parah terhadap infeksi agen. Oleh karena itu, gaya hidup dan nutrisi yang tepat dengan mempertahankan homeostasis dari respon imun tidak hanya melindungi tubuh manusia tetapi juga mengurangi risiko morbiditas dan mortalitas karena peradangan yang tidak dapat dijelaskan jika terjadi epidemi dan pandemi seperti SARSCoV2 (Boroujeni et al., 2020). Penelitian ini dilakukan untuk menganalisis pengetahuan masyarakat terhadap gaya hidup di rumah saja pada era new normal. 


\section{METODE}

Desain penelitian yang digunakan ini adalah quasi eksperimental pre dan posttest desain melalui seminar online yang bertujuan untuk menganalisis pengetahuan masyarakat terhadap gaya hidup di rumah saja pada era new normal. Data yang digunakan pada penelitian ini terdiri dari data primer yang diperoleh dari sebaran kuesioner. Penelitian ini merupakan jenis penelitian analisis deskriptif dengan menggunakan pendekatan kuantitatif.

Peneliti memberikan kuesioner yang disebar secara acak kepada masyarakat umum Indonesia. Untuk kuesioner, skala pengukuran yang digunakan adalah skala Likert dengan rentang nilai 1-5. $5=$ Sangat Setuju, $4=$ Setuju, $3=$ Normal, $2=$ Tidak Setuju, 1 = Sangat Tidak Setuju. Analisa data yang digunakan yaitu analisis deskriptif mengetahui distribusi frekuensi berdasarkan pengetahuan sedangkan analisis analitik menggunakan uji wilcoxon untuk mengetahui perbedaan pengetahuan masyarakat terhadap gaya hidup di rumah saja pada era new normal sebelum dan sesudah dilaksanakannya seminar online.

\section{HASIL}

\section{Karakteristik Subjek Penelitian}

Pada penelitian ini menggunakan sampel masyarakat Indonesia sebanyak 93 orang. Distribusi subjek penelitian ini merupakan usia, jenis kelamin, dan pekerjaan. Distribusi kelompok usia banyak ditemukan di bawah 21-44 tahun yaitu 71 orang $(76,3 \%)<20$ tahun $10(10,8 \%)$ dan $\geq$ 45 tahun 12 orang $(12,9)$. Dalam penelitian ini terdapat $29(31,2)$ laki-laki dan 64 $(68,8)$. Tingkat Pendidikan SD $1(1,1 \%)$, SMP 7 (7,5\%) SMK/SMA 20 (21,5\%) dan Sarjana 65 (69,9\%). Untuk distribusi pekerjaan terdapat PNS sebanyak 21 $(22,6 \%)$, karyawan swasta $24(25,8 \%)$, wiraswasta $7(7,5 \%)$, buruh $1(1,1 \%)$, belum bekerja $40(43,0 \%)$. Hasil analisis disajikan pada tabel 1 .

Tabel 1. Karakteristik Responden

\begin{tabular}{lll}
\hline Varaibel & $\begin{array}{l}\text { Jumlah } \\
(\mathbf{n = 9 3})\end{array}$ & $\begin{array}{l}\text { Presentase } \\
(\mathbf{\%})\end{array}$ \\
\hline Usia & & \\
$<20$ tahun & 10 & 10,8 \\
20-44 tahun & 71 & 76,3 \\
$\geq 45$ tahun & 12 & 12,9 \\
\hline Jenis Kelamin & & \\
Laki-laki & 29 & 31.2 \\
Perempuan & 64 & 68.8 \\
\hline Pendidikan & & \\
SD & 1 & 1.1 \\
SMP & 7 & 7.5 \\
SMA/SMK & 20 & 21.5 \\
Sarjana & 65 & 69.9 \\
\hline Pekerjaan & & \\
PNS & 21 & 22.6 \\
Karyawan & 24 & 25,8 \\
swasta & 7 & 7,5 \\
Wiraswasta & 1 & 1,1 \\
Buruh & 40 & 43,0 \\
Belum bekerja & & \\
\hline & &
\end{tabular}

Pengetahuan Masyarakat Indonesia terhadap Gaya Hidup di Rumah Saja pada Era New Normal

Berikut merupakan hasil analisis pengetahuan masyarakat Indonesia mengenai beraktivitas di era new normal. Menurut Arikunto (2006) pengetahuan dapat dikategorikan baik bila jawaban benar berada dalam rentang $75 \%$ dari keseluruhan pertanyaan (Mail et al., 2020). Dalam penelitian ini pengetahuan dikategorikan baik bila skor $\geq 15$. Perilaku masyarakat sebelum seminar didapati baik sebanyak 82 orang $(88,2 \%)$, cukup $10(10,8 \%)$, dan kurang 1 $(1,1 \%)$. Perilaku setelah seminar didapati baik sebanyak 88 (94,6\%), cukup $4(4,3 \%)$, dan kurang $1(1,1 \%)$ Hasil analisis pengetahuan baik disajikan dalam gambar 1 .

Gambar 1. Pengetahuan baik masyarakat Indonesia terhadap gaya hidup dirumah saja p di era new normal sebelum dan setelah seminar

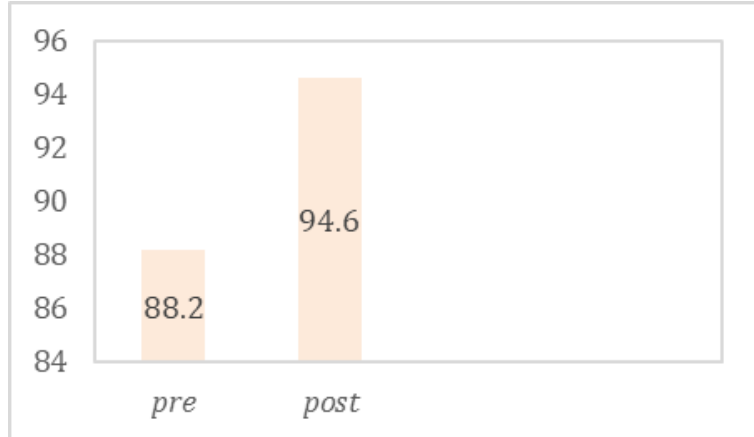




\section{Uji Normalitas}

Hasil uji normalitas pengetahuan masyarakat tetang perilaku masyarakat terhadap gaya hidup di rumah saja pada era new normal sebelum dan selepas seminar. Didapatkan bahwa pengetahuan sebelum $(p=0,000)$ dan pengetahuan setelah $(\mathrm{p}=0,000)$, hal ini menunjukkan bahwa data sebelum dan selepas tidak terdistribusi normal $(\mathrm{p}<0,05)$. Hasil analisis disajikan pada tabel 2 .

Tabel 2. Uji Normalitas Pengetahuan Shapiro-Wilk

\begin{tabular}{llll}
\hline & Statistic & Df & Sig \\
\hline Pre & .865 & 93 & .000 \\
Post & .690 & 93 & .000 \\
\hline
\end{tabular}

\section{Perbedaan Pengetahuan Pengaruh Perilaku Masyarakat terhadap Gaya Hidup di Rumah Saja pada Era New Normal}

Analisis perbedaan pengetahuan masyarakat Indonesia tentang perilaku masyarakat terhadap gaya hidup di rumah saja pada era new normal. Hasil uji statistik menggunakan uji wilcoxon didapatkan bahwa ada perbedaan yang bermakna rerata pengetahuan sebelum dan setelah penggunaan media promosi kesehatan ( $\mathrm{p}$ 0,000), artinya ada perbedaan atau perubahan skor pengetahuan antara responden sebelum dan sesudah dilakukan seminar online. Hasil analisis disajikan pada tabel hasil analisis disajikan dalam bentuk tabel 3 .

Table 3. Uji Wilcoxon

\begin{tabular}{llll}
\hline Pengetahuan & N & Rerata \pm SD & p value \\
\hline Pretest & 93 & $17,52 \pm 2,311$ & \multirow{2}{*}{0,000} \\
Post-test & 93 & $18,66 \pm 2,083$ & \\
\hline$U j$ Witcoxon $p<0,05$ &
\end{tabular}

Uji Wilcoxon $p<0,05$

\section{PEMBAHASAN}

Meskipun periode karantina adalah pilihan terbaik untuk mengurangi infeksi Covid-19 yang menyebar dengan cepat, tetapi ini memiliki efek yang lain dari kesehatan pasien yang terisolasi, dan terutama pada mereka yang berisiko lebih tinggi. Keadaan karantina yang menyebabkan perubahan dalam gaya hidup penduduk (Pavon et al., 2020). Gaya hidup dan perilaku ini dalam banyak kasus termasuk tingkat aktivitas fisik tertentu dan olahraga untuk mempertahankan status kesehatan yang memadai, untuk menangkal dampak negatif dari penyakit tertentu, seperti diabetes, hipertensi, CVD, penyakit pernapasan, atau bahkan hanya untuk menjamin penuaan aktif dengan mengurangi risiko kelemahan, sarkopenia dan demensia, sebagai penyakit terkait pada orang tua. Selain itu, dampak psikologis, termasuk gejala stres pasca-trauma, kebingungan, dan kemarahan telah dilaporkan (Lavie et al., 2019). Faktorfaktor stres yang disarankan termasuk durasi karantina yang lebih lama, ketakutan akan infeksi, frustrasi, kebosanan, persediaan yang tidak memadai, informasi yang tidak memadai, kerugian finansial, dan stigma (Ozemek et al., 2019).

Berdasarkan penelitian ini jumlah responden yang terbanyak adalah perempuan $(68,8 \%)$ dan kebanyakkan responden dari penelitian ini belum bekerja (43\%). Menurut penelitian Syadidurrahmah et al., (2020) menunjukkan bahwa jenis kelamin, pengetahuan terkait dengan physical distancing dan dukungan keluarga memiliki hubungan dengan perilaku physical distancing mahasiswa UIN Syarif Hidayatullah Jakarta. Pada penelitian ini, didapati proporsi perilaku physical distancing yang baik sebesar 55,9\%. Sebanyak $63,1 \%$ perempuan perilaku physical distancing yang baik. Tambahan lagi, mahasiswa perempuan cenderung untuk menerapkan perilaku physical distancing baik 3,4 kali dibandingkan dengan laki-laki (CI 95\% 2,037-5,804). Hal ini disebabkan karena perempuan pada umumnya menekankan pengertian sehat terkait dengan gaya hidup seperti relaksasi, istirahat, perasaan sehat, dan nutrisi, sedangkan laki-laki menekankan pada keadaan tidak sakit. Oleh karena itu, 
perempuan lebih berhati-hati, cenderung menerapkan perilaku gaya hidup sehat (Syadidurrahman et al., 2020). Berdasarkan penelitian, wanita lebih tertarik untuk memperoleh informasi mengenai kesehatan (Moudy \& Syakurah, 2020).

Selain itu, konsekuensi utama karantina adalah perubahan gaya hidup dan kebiasaan gizi. Kebiasaan gizi akan berubah karena berkurangnya ketersediaan barang, akses terbatas untuk makanan yang disebabkan oleh jam buka toko terbatas, dan untuk beralih ke makanan yang tidak sehat. Persediaan dasar yang tidak memadai (misalnya makanan, air) selama karantina adalah sumber frustrasi dan terus dikaitkan dengan kecemasan dan kemarahan untuk 46 bulan setelah rilis. Oleh karena kecemasan akan kekurangan makanan di masa depan maka wajar orang-orang akan membeli makanan kemasan daripada makanan yang segar. Hal ini menyebabkan penambahan berat badan dan berkurangnya asupan antioksidan. Makanan yang kaya akan buah-buahan dan sayuran memiliki beberapa efek positif: manfaat kesehatan yang diketahui asupan flavonol tinggi, potensi peningkatan oksida nitrat spesies, penurunan berat badan secara bersamaan, pengurangan tekanan darah, dan pengurangan penanda inflamasi. Efek ini menguntungkan pada pria dan wanita meskipun fakta bahwa kepatuhan terhadap diet dan gaya hidup sehat dipengaruhi berdasarkan jenis kelamin (Mattioli et al., 2020).

Berdasarkan usia dan tingkat pendidikan pada penelitian ini didapatkan bahwa kebanyakan responden berumur 2045 tahun $(76,3)$ dan tamatan sarjana $(69,9)$. Masyarakat kelompok usia dua puluh satu hingga tiga puluh tahun dengan mayoritas tingkat pendidikan tamat sarjana, diploma, dan magister memilih internet sebagai media massa konsumsi utama (Nur, 2014). Berdasarkan penelitian, penggunaan internet seperti Google dapat menjadi sarana peringatan dini dan monitoring dalam perbaikan sistem imun pada masa pandemi Covid-19 (Amelia \& Syakurah, 2020).

Berdasarkan nilai post-test yang didapat, target yang efektif pada penelitian ini juga tercapai yaitu nilai post-test sama dengan atau lebih dari $75 \%$. Promosi kesehatan menggunakan seminar online mengenai gaya hidup di rumah pada era new normal efektif meningkatkan pengetahuan masyarakat Dalam seminar online, presentasi, kuliah, pelatihan atau konten serupa akan dikirimkan melalui Internet menggunakan teknologi video. Perangkat lunak konferensi website digunakan untuk tujuan ini, yang tidak berfungsi untuk mengirimkan acara ke website, tetapi juga dapat digunakan untuk mengelola dan berkomunikasi dengan peserta. Sebuah webinar secara teoritis hanya terdiri dari data audio, tetapi biasanya merupakan transmisi gambar webcam, konten desktop komputer, atau keduanya (Durahman \& Noer, 2019). Pengetahuan masyarakat mempengaruhi upaya pencegahan Covid-19. Pemberian informasi juga harus valid, spesifik dan tepat $\operatorname{sasaran}^{14}$. Berdasarkan penelitian, pengetahuan masyarakat Indonesia mengenai Covid-19 sudah baik (Linardi et al., 2021).

Mengenai pedoman gaya hidup, ulasan baru-baru ini telah menekankan peranan mempertahankan status kesehatan kesehatan dan terlibat dalam latihan fisik di rumah dalam pengelolaan wabah Covid-19 (Zachary et al., 2020). Rekomendasi serupa dibuat pada saat pandemi influenza pada tahun 1918, ketika kesehatan masyarakat mengikuti konsep kebersihan, nutrisi, udara segar dan istirahat yang baik. Namun, pedoman gaya hidup itu tidak berdasarkan bukti. Data pengamatan tentang bagaimana masyarakat umum dan pasien dengan gangguan kejiwaan sebenarnya berhubungan dengan perawatan diri, nutrisi, aktivitas fisik atau tidur restoratif selama penahanan masih kurang dan merupakan kesenjangan penelitian (Zhang et al., 2020). 
Sehubungan dengan perubahan gaya hidup selama kuarantina Covid-19, sebagian besar populasi menyatakan tidak mengubah kebiasaannya $(46,1 \%)$, sementara $16,7 \%$ dan $37,2 \%$ merasa demikian masing-masing telah meningkatkan atau memperburuknya. Secara khusus, kebiasaan merokok telah berkurang selama kuncian (nilai McNemar $=101.484, \mathrm{p}<0.001$ ), dan jam tidur meningkat (nilai McNemar $=330.851, \mathrm{p}$ $<0,001$ ), dengan pertimbangan yang sama Utara, Tengah, dan Selatan Italia (data tidak ditampilkan). Mengenai aktivitas fisik, tidak ada perbedaan signifikan antara persentase orang yang tidak berlatih sebelum $(37,7 \%)$ atau selama $(37,4 \%)$ Covid-19 kuncian diamati $(\mathrm{p}=0,430)$. Sebaliknya, frekuensi pelatihan yang lebih tinggi selama keadaan darurat adalah ditemukan ketika dibandingkan dengan periode sebelumnya (McNemar nilai $=$ 259.529, p <0,001) (Renzo et al., 2020).

Covid-19 memengaruhi lebih banyak pria daripada wanita. Hal ini disebabkan karena pria memiliki tingkat penyakit kronis yang lebih tinggi, faktor risiko untuk Covid-19. Pasien Covid-19 yang parah memiliki kadar sitokin Th1 (IL-6 dan TNF$\alpha$ ) yang secara signifikan lebih tinggi dan tingkat insiden ARDS yang lebih tinggi, dibandingkan dengan kasus yang tidak parah, menunjukkan respons inflamasi yang lebih intens. Diketahui bahwa setelah kerusakan iskemik, laki-laki memiliki tingkat IL-6 yang jauh lebih tinggi. Selain itu, kerusakan otot akibat olahraga memicu respons inflamasi yang mengakibatkan peningkatan penanda inflamasi seperti protein C-reaktif (CRP) dan beberapa interleukin inflamasi (IL-1, IL-6) dan faktor nekrosis tumor (TNF- $\alpha$ ) (Mattoli et al., 2020).

Aktivitas fisik rutin mengurangi protein IL-6 dan C-reaktif. Biasanya wanita kurang aktif secara fisik daripada pria dan kesenjangan meningkat setelah menopause. Selama dan setelah menopause, kebanyakan wanita cenderung mengurangi tingkat aktivitas fisik mereka dan bersama- sama dengan penurunan tingkat metabolisme basal, ini menyebabkan hilangnya massa otot rangka serta hilangnya kepadatan mineral tulang. Selama periode perimenopause, pengendapan lemak bergeser untuk mendukung depot visceral, di samping penurunan efek perlindungan estrogen, berkontribusi terhadap disfungsi endotel, peradangan, metabolisme asam lemak yang berubah, resistensi insulin, dan semua penanda CVD (Mattoli et al., 2020).

Ada hubungan langsung antara waktu yang dihabiskan untuk duduk, aktivitas fisik, dan risiko CVD pada wanita pascamenopause, terlepas dari aktivitas fisik waktu luang. Waktu duduk yang lama menentukan banyak adaptasi yang merugikan, seperti peningkatan asupan energi dan pengurangan aktivitas lipoprotein lipase otot rangka yang mungkin menjelaskan pengaruhnya terhadap faktor risiko kardiovaskular. Selain itu, keinginan makanan yang dijelaskan memiliki prevalensi lebih tinggi pada wanita dibandingkan pada pria. Karantina menginduksi pengurangan aktivitas fisik dan peningkatan waktu duduk yang mengarah pada peningkatan risiko kardiovaskular pada wanita (Mattoli et al., 2020). Adalah wajib untuk mempromosikan seruan tindakan bagi wanita sebagian besar setelah 40 tahun, untuk gaya hidup sehat selama karantina untuk mengurangi, sebagai konsekuensinya, risiko kardiovaskular (Li et al., 2020).

Menurut Kotler dalam Utama (2020), gaya hidup adalah pola hidup seseorang dalam dunia kehidupan sehari hari yang dinyatakan dalam kegiatan, minat, dan pendapat yang bersangkutan. Hal ini menunjukkan keseluruhan pola perilaku seseorang dalam kehidupan sehari-hari. Gaya hidup merupakan indikator berupa komposit variabel yang disusun/dihitung dari 5 (lima) variabel yaitu kebiasaan cuci tangan, kebiasaan buang air besar, kebiasaan merokok satu bulan terakhir, aktifitas fisik, dan kebiasaan konsumsi 
buah dan sayur. Perilaku konsumsi makanan sebagai salah satu variabel (Utama, 2020).

Gaya hidup pada umumnya menunjukkan adanya hubungan/ asosiasi dengan kesehatan. Penelitian lain pada para pegawai sipil yang juga dilakukan di Jepang menunjukkan adanya asosiasi antara kesehatan dan kebiasaan merokok (Simonsick et al., 2016). Asosiasi antara aktivitas fisik sebagai salah satu variabel gaya hidup mempunyai asosiasi dengan kejadian kesehatan. Status kesehatan yang baik berhubungan dengan tingginya frekuensi aktivitas fisik, tidak konsumsi alkohol/konsumsi tidak berlebih, tidak merokok, dan tidak underweight atau over weight (Velten, 2014).

Survei online yang dilakukan oleh news-18 di seluruh India terhadap 40.700 orang yang bertujuan untuk memeriksa KAP tentang virus korona. Sekitar 76\% responden dari seluruh India mengatakan bahwa mereka menjaga kebersihan diri dan memastikan lingkungan yang bersih, menghindari tempat-tempat ramai dan menggunakan masker wajah saat bepergian yang sangat mirip dengan hasil penelitian Nazli T et al. (2020) di mana 79,6\% responden menyadari bahwa masker wajah berguna untuk mencegah infeksi coronavirus dan $77,3 \%$ mempraktikkan jarak sosial (Nazli et al., 2020). Pertahankan jarak setidaknya 1 meter (3 kaki) sesuai WHO atau setidaknya 6 kaki (2 meter) sesuai CDC (CDC, 2021b).

\section{KESIMPULAN}

Dari penelitian ini dapat disimpulkan bahwa mayoritas pengetahuan masyarakat terhadap gaya hidup di rumah saja pada era new normal sudah baik dan dari hasil analisis didapatkan perbedaan pengetahuan masyarakat sebelum dan sesudah dilakukan seminar online.

\section{UCAPAN TERIMAKASIH}

Penulis mengucapkan terimakasih kepada semua responden dan staf bagian Ilmu Kesehatan Masyarakat Ilmu Kedokteran Komunitas Fakultas Kedokteran Universitas Sriwijaya, Palembang, Sumatera Selatan, Indonesia.

\section{DAFTAR PUSTAKA}

Amelia, L. \& Syakurah, R. A. (2020) 'Analysis Of Public Search Interest Towards Immune System Improvement During The Covid-19 Pandemic In Indonesia Using Google Trends', IJPHS ,9(4).

Boroujeni, S. A., Sani, M., \& Reza, M. (2020) 'COVID-19 Pandemic along with Pandemic of LifestyleAssociated Diseases Victimizes Patients in an Inflammation Context!', Dubai Med J, 3, pp. 55-57.

CDC (2021a) People with Certain Medical Conditions.

[Internet]. https://www.cdc.gov/coronavirus/201 9-ncov/need-extra-

precautions/people-with-medicalconditions.html

CDC (2021b) COVID-19 Overview and Infection Prevention and Control Priorities in non-US Healthcare Settings. [Internet]. https://www.cdc.gov/coronavirus/201 9-ncov/hcp/non-ussettings/overview/.

Durahman, N. \& Noer, Z. M. (2019) 'Aplikasi Seminar Online (Webinar) Untuk Pembinaan Wirausaha Baru', Jumika 2(6).

Hammami, A., Harrabi, B., Mohr, M., \& Krustrup, P. (2020) 'Physical activity and coronavirus disease 2019 (COVID-19): specific recommendations for home-based physical training', Managing Sport and Leisure, pp. 1-6.

Kanneth, M. (2020) 'Coronavirus disease 2019 (COVID-19)', UpToDate, pp. 127. 
Lavie, C. J., Ozemek, C., Carbone, S., Katzmarzyk, P. T., \& Blair, S. N. (2019) 'Sedentary behavior, exercise, and cardiovascular health', Circ Res, 124(5), pp. 799-815.

Li, X., Xu, S., Yu, M., Wang, K., Tao, Y., Zhou, Y., et al. (2020) 'Risk factors for severity and mortality in adult COVID-19 inpatients in Wuhan', $J$ Allergy Clin Immunol.

Linardi, V., Syakurah, R. A., \& Moudy J. (2021) 'Demography Factor Influencing Indonesian General Knowledge on Covid-19', IJPHS, 10(1).

Mail, N. A., Barek, P. A. L., \& Besin, V. (2020) 'Gambaran Tingkat Pengetahuan Remaja Tentang Kesehatan Reproduksi di SMPN Haliwen', Jurnal Sahabat Keperawatan, 2(2), pp. 1-6.

Mattioli, A. V., Puviani, M. B., Nasi, M., \& Farinetti, A. (2020) 'CTIVE COVID19 pandemic: the effects of quarantine on cardiovascular risk', European Journal of Clinical Nutrition, 74, pp. 852-855.

Mattioli, A. V., Sciomer, S., Cocchic, C., et al. (2020) 'Quarantine during COVID-19 outbreak: Changes in diet and physical activity increase the risk of cardiovascular disease', PubMed 30(9), pp. 1409-1417.

Muscogiuri, G., Barrea, L., Annunziata, G., Somma, D. C., Laudisio, D., Colao, A., \& Savastano, S. (2019) 'Obesity and sleep disturbance: the chicken or the egg?', Crit Rev Food Sci Nutr, 59, pp. 2158-65.

Muscogiuri, G., Barrea, L., Aprano, S., Framondi, L., et al. (2020) 'Sleep quality in obesity: does adherence to the mediterranean diet matter?', Nutrients, 12, pp. 1364.

Nazli, T., Heena, Raheem, A., \& Kishore, J. (2020) 'Perceptions and Practices of the Adult Population in Response to SARS-CoV-2 Pandemic in India', Epidem Int, 5(2), pp. 10-16.
Nur (2014) 'Pengaruh Usia, Tingkat Pendidikan, dan Jenis Kelamin Terhadap Perilaku Konsumsi Media', Interaksi Online, 4(2).

Ozemek, C., Lavie, C. J., \& Rognmo, Ø. (2019) 'Global physical activity levels: need for intervention', Prog Cardiovasc Dis, 62(2), pp. 102-107.

Pavón, D. J., Baeza, A. C., \& Lavie, C. J. (2020) 'Physical exercise as therapy to fight against the mental and physical consequences of COVID-19 quarantine: Special focus in older people', Prog Cardiovasc Dis, 63(3), pp. 86-388.

Pedersen, B. K., \& Saltin, B. (2015) 'Exercise as medicine - evidence for prescribing exercise as therapy in 26 different chronic diseases. Scandinavian', Journal of Medicine \& Science in Sports, 25(S3), pp. 1-72.

Renzo, L. D., Gualtieri, P., Pivari, F., et.al. (2020) 'Eating habits and lifestyle changes during COVID-19 lockdown: an Italian survey', Journal of Translational Medicine, 229(18).

Simonsick, E. M., Meier, H. C. S., Shaffer, N. C., Studenski, S. A., \& Ferrucci, L. (2016) 'Basal body temperature as a biomarker of healthy aging Age', Dordr, 38(5-6), pp. 445-454.

Syadidurrahmah, et al. (2020) 'Perilaku dan Promosi Kesehatan', Indonesian Journal of Health Promotion and Behavior, 2(1), 29-37.

Moudy, J. \& Syakurah, R. A. (2020) 'Pengetahuan terkait Usaha Pencegahan Coronavirus Disease (COVID-19) di Indonesia', HIGEIA (Journal of Public Health Research and Development), 4(3), pp. 333-346.

Utama, L. J. (2020) 'Gaya Hidup Mayarakat Nusa Tenggara Timur Dalam Menghadapi Pandemi Corona Virus Disease 19 (COVID-19)', AnNadaa: Jurnal Kesehatan Masyarakat, 7(1), pp. 34-40.

Velten, J., Lavallee, K. L., Scholten, S., et al. (2014) 'Lifestyle choices and mental health: a representative 
population survey', BMC Psychol, $58(2)$.

WHO (2021) Coronavirus. [Internet]. https://www.who.int/healthtopics/coronavirus

Zachary, Z., Brianna, F., Brianna, L., et.al. (2020) 'Self-quarantine and Weight Gain Related Risk Factors During the COVID-19 Pandemic, Obesity Research \& Clinical Practice', 10.1016/j.orcp.2020.05.004.

Zhang, L. \& Liu, Y. (2020) 'Potential interventions for novel coronavirus in China: a systemic review', J Med Virol, 92, pp. 479-490. 